\title{
One Year Data of New Secondary Glaucoma Patients at Top Referral Eye Hospital in Indonesia
}

\author{
Elka Rifqah, ${ }^{1}$ Elsa Gustianty, ${ }^{2}$ Ihrul Prianza Prajitno ${ }^{3}$ \\ ${ }^{1}$ Faculty of Medicine Universitas Padjadjaran, ${ }^{2}$ Department of Ophthalmology Faculty of Medicine \\ Universitas Padjadjaran/National Eye Center Cicendo Eye Hospital, ${ }^{3}$ Department of Anatomy, Cell \\ Biology and Physiology Faculty of Medicine Universitas Padjadjaran
}

\begin{abstract}
Background: Glaucoma is the second most common cause of blindness after cataract in the world and also in Indonesia. Based on the etiology, glaucoma is classified into primary and secondary glaucoma. Secondary glaucoma can cause severe visual function disorders and affect the patient's quality of life. This study was carried out to indentify the characteristics of new secondary glaucoma patients at Cicendo Eye Hospital from January to December 2013.

Methods: This descriptive study was carried out at Cicendo Eye Hospital from November to December 2014. Secondary data were retrieved from medical records of new secondary glaucoma patients who came to the Glaucoma unit from January to December 2013. Inclusion criteria were medical records comprising data about age, gender, location of the affected eyes by secondary glaucoma, etiology of secondary glaucoma and value of intraocular pressure. The collected data were recorded and analyzed to illustrate their frequency distribution and proportion.

Results: Out of 63 patients, $42.9 \%$ was $40-59$ years old and $63.5 \%$ was men. Most cases were unilateral $(82.5 \%)$. It was found that 74 eyes (52 unilateral, 11 bilateral), diagnosed as secondary glaucoma, had intraocular pressure $\geq 30 \mathrm{mmHg}$ which were $54.1 \%$. Secondary glaucoma were caused by lens induced (36.5\%), inflammation (22.2\%), and trauma (9.5\%).

Conclusions: Most cases are middle-aged patients and dominated by men. The eye diagnosed as secondary glaucoma occurred more in the unilateral eye which has intraocular pressure $\geq 30 \mathrm{mmHg}$ and is caused by lens induced and inflammation.
\end{abstract}

Keywords: Secondary glaucoma, inflammation, lens induced

\section{Introduction}

Visual impairment is one of the health issues of concern around the world. Approximately 285 million people are estimated to be visually impaired worldwide, 39 million are blind and 246 have low vision. ${ }^{1}$

Glaucoma is the second leading cause of blindness after cataract in the world. ${ }^{2-4}$ According to the results of the National Survey of Health Sense in 8 provinces in 1993-1996, the prevalence of blindness in Indonesia was $1.5 \%$ and from that percentage, $0.2 \%$ caused by glaucoma. The results of the Survey of Blindness and Eye Health in West Java in 2005 , showed that the prevalence of glaucoma in the age group above 40 was $1.2 \%$ and the prevalence of blindness due to glaucoma was

\section{$0.1 \%$ from $4.0 \%$ of total blindness. ${ }^{5}$}

Glaucoma is a chronic optic neuropathy with presence of damage of the optic disc and progressive derivation of visual field. Based on the etiology, glaucoma is classified into primary and secondary glaucoma. Primary glaucoma is not caused by glaucoma or ocular systemic disorders, while secondary glaucoma results from the manifestation of ocular disorders or systemic disorders. ${ }^{6}$

Cicendo Eye Hospital is a government, top referral and an academiceye hospital. Since 24 April 2010, this hospital has been designated as a national referral eye hospital. ${ }^{7}$ This study was conducted to investigate the characteristics of secondary glaucoma patients in Cicendo Eye Hospital from January to December 2013.

Correspondence: Elka Rifqah, Faculty of Medicine, Universitas Padjadjaran, Jalan Raya Bandung-Sumedang Km.21, Jatinangor, Sumedang, Indonesia, Phone: +62 81905501090, Email: rifqah.lk@gmail.com 


\section{Methods}

A descriptive study was carried out using medical records of secondary glaucoma patients who went to the glaucoma unit of the Cicendo Eye Hospital from January to December 2013. The inclusion criteria were medical records consisting of new secondary glaucoma patients and information about their age, gender, the location of eyes affected by secondary glaucoma, etiology of the secondary glaucoma and value of intraocular pressure. Moreover, the exclusion criteria were medical records with incomplete data. The collected data were recorded and analyzed to obtain the frequency distribution and proportion.

\section{Results}

A total of 63 medical records of new secondary glaucoma patients were collected from January to December 2013. According to their age, most of the patients were middle-aged (40-59 years) and the number of cases were declined in old age. Moreover, this study discovered that men were the most affected by these disorders. According to the location of the eyes affected by these disorders, in most cases, only one eye (unilateral) was affected (Table 1).

Cases of secondary glaucoma in this study were most often caused by lens induced in 23 cases $(36.5 \%)$, followed by inflammation in 14 cases $(22.2 \%)$ (Table 2).

Out of 63 cases of secondary glaucoma, 52 cases occurred in one eye (52 eyes) and 11 cases occurred in both eyes (22 eyes), so that the total number of eyes with secondary glaucoma was 74 eyes. This study showed the most common secondary glaucoma had intraocular pressure of $\geq 30 \mathrm{mmHg}$.

\section{Discussion}

The results of this study showed that cases of secondary glaucoma in the new patient category in 2013 at Cicendo Eye Hospital occurred more in the age range 40-59 years, because the highest etiology (lens induced) caused by senile cataract occurs at the age of 40 years, as described by Gupta et al. ${ }^{8}$

This study showed that secondary glaucoma was more common in men than women; this was unlike the study of Sakata, et al. ${ }^{9}$ which reported more cases of secondary glaucoma in women. The study of Sihota et al. ${ }^{10}$ revealed that the secondary glaucoma due to trauma occurs more in men. Although there was a difference between the number of men and women, this difference did not show any relationship between sex and incidence of glaucoma, as described by Shen et al. ${ }^{11}$, and Khandekar et al. ${ }^{12}$

This study showed that secondary glaucoma was more common in the unilateral eye, which is similar to the study conducted by Gadia et al. ${ }^{13} \mathrm{~A}$ study by Bodh et al. ${ }^{14}$ showed that cases of glaucoma due to inflammation occurs more in bilateral cases.

This study discovered that the secondary glaucoma occured due to eye diseases such as lens induced, uveitis, phacomorphic, side effects of corticosteroid, traumatic cataract and other eye diseases. A study by Yaakub, et al. ${ }^{15}$ showed that the secondary glaucoma due to lens-induced glaucoma could occur because of a dislocated lens, lens swelling or inflammation due to phacoanaphilactic and is common in developing countries. Some conditions that

Table 1 Patient Distribution by Gender, Age and Eyes Laterality

\begin{tabular}{lccc}
\hline & Men & Women & Frequency \\
\hline Age & & & \\
$14-39$ years & $12(19.1 \%)$ & $5(7.9 \%)$ & $17(27 \%)$ \\
$40-59$ years & $15(23.8 \%)$ & $12(19.1 \%)$ & $27(42.9 \%)$ \\
$\geq 60$ years & $13(20.6 \%)$ & $6(9.5 \%)$ & $19(30.2 \%)$ \\
$\quad$ Total & $40(63.5 \%)$ & $23(36.5 \%)$ & $63(100 \%)$ \\
Eye laterality & & & \\
$\quad$ Unilateral & $32(50.8 \%)$ & $20(31.7 \%)$ & $52(82.5 \%)$ \\
Bilateral & $8(12.7 \%)$ & $3(4.8 \%)$ & $11(17.5 \%)$ \\
Total & $40(63.5 \%)$ & $23(36.5 \%)$ & $63(100 \%)$ \\
\hline
\end{tabular}


Table 2 Characteristic of Etiology

\begin{tabular}{|c|c|c|}
\hline Etiology & Frequency Distribution & $\%$ \\
\hline Lens induced & 23 & 36.5 \\
\hline Phacomorphic & 6 & 9.5 \\
\hline Immature senile cataract & 6 & 9.5 \\
\hline Ectopic lens & 1 & 1.6 \\
\hline Phacolytic glaucoma & 1 & 1.6 \\
\hline Mature senile cataract & 1 & 1.6 \\
\hline others & 8 & 12.7 \\
\hline Inflammation & 14 & 22.2 \\
\hline Anterior uveitis & 5 & 7.9 \\
\hline Panuveitis & 2 & 3.2 \\
\hline Glaucomatous cyclitic crisis & 1 & 1.6 \\
\hline Panophtalmitis & 1 & 1.6 \\
\hline Bilateral uveitis & 1 & 1.6 \\
\hline others & 4 & 6.3 \\
\hline Trauma & 6 & 9.5 \\
\hline Hiphema & 2 & 3.2 \\
\hline Traumatic cataract & 2 & 3.2 \\
\hline Iridoplegi & 1 & 1.6 \\
\hline others & 1 & 1.6 \\
\hline Pseudophakia/aphakia & 5 & 7.9 \\
\hline Steroid induced & 4 & 6.3 \\
\hline Neovascular glaucoma & 3 & 4.8 \\
\hline Others & 8 & 12.7 \\
\hline Keratopati & 3 & 4.8 \\
\hline Ulcus cornea & 2 & 3.2 \\
\hline Axenfeld rieger syndrome & 1 & 1.6 \\
\hline Absolut glaucoma & 1 & 1.6 \\
\hline Suprachoroidal hemorrhage & 1 & 1.6 \\
\hline Total & 63 & 100 \\
\hline
\end{tabular}

increase the risk of secondary glaucoma caused by corticosteroid is diabetes mellitus, myopia, and rheumatoid arthritis. ${ }^{16}$ A study by
Bodh et al. ${ }^{14}$ revealed that glaucomatocyclitic crisis associated with immunogenetic factor and cause of intraocular pressure rises to 40 -

Table 3 Distribution of Intraocular Pressure among Secondary Glaucoma Patients

\begin{tabular}{lcc}
\hline \multicolumn{1}{c}{ Intraocular Pressure } & Number of Eyes & \% \\
\hline $21,0-29,9 \mathrm{mmHg}$ & 19 & 25.7 \\
$\geq 30 \mathrm{mmHg}$ & 40 & 54.1 \\
Difficult to assess & 15 & 20.3 \\
Total & 74 & 100,0 \\
\hline
\end{tabular}


$70 \mathrm{mmHg}$ during acute attack.

Furthermore, normal intraocular pressure ranges from 11-21 $\mathrm{mmHg}$, although there is no absolute pathological point, $21 \mathrm{mmHg}$ is considered as the upper limit of normal intraocular pressure. In some cases, the manifestation of glaucoma occurs with intraocular pressure less than $21 \mathrm{mmHg}$. However, in other cases the intraocular pressure rises to $30 \mathrm{mmHg}$ without manifestation of glaucoma. ${ }^{17}$ This study showed the majority of cases occurred with secondary glaucoma intraocular pressure $\geq 30$ mmHg. A study of Yaakub et al. ${ }^{15}$ showed that the intraocular pressure is between 40-49 $\mathrm{mmHg}$ in lens-induced glaucoma patients in Malaysia.

Limitations of this study are the difficulties to access the medical record and limited time. The conclusions of this study are that secondary glaucoma patients occurred more in men than in women, and most are in the age range 40-59 years. The most common etiology of these disorders is lens induced glaucoma. Secondary glaucoma is more common in one eye (unilateral) with intraocular pressure $\geq 30$ mmHg.

\section{References}

1. World Health Organization. Visual Impairement and Blindness. 2013 [cited 2014 March 11]. Available from: http:// www.who.int/mediacentre/factsheets/ fs $282 / \mathrm{en} /$.

2. World Health Organization. Glaucoma is second leading cause of blindness globally.2004 [cited 2014 March11]. Available from: http://www.who.int/ bulletin/volumes/82/11/feature1104/ en/.

3. Quigley HA, Broman AT. The number of people with glaucoma worldwide in 2010 and 2020. Br J Ophthalmol. 2006; $90(3): 262-7$.

4. Iwase A, Araie M, Tomidokoro A, Yamamoto T, Shimizu H, Kitazawa Y. Prevalence and causes of low vision and blindness in a Japanese adult population: the Tajimi Study. Ophthalmology. 2006;113(8):135462.

5. Kementrian Kesehatan Republik Indonesia. Gangguan Penglihatan Masih Menjadi
Masalah Kesehatan 2013 [cited 2014 March 11]. Available from: http://www. depkes.go.id/index.php?vw=2\&id=845.

6. American Academy of Ophthalmology. Glaucoma. 2011.

7. Kementrian Kesehatan Republik Indonesia. Menkes Resmikan RS Mata Cicendo Sebagai Pusat Mata Nasional.2010 [cited 2014 March 11]. Available from: http://www. depkes.go.id/index.php?vw=2\&id=1063.

8. Gupta P, Bhagotra S, Prakash S. Pattern and visual outcome in lens induced glaucoma. JK Science Journal of Medical Education and Research. 2012;14(4):181-4.

9. Sakata K, Sakata LM, Sakata VM, Santini C, Hopker LM, Bernardes R, etal. Prevalence of glaucoma in a South Brazilian population: Projeto Glaucoma. Invest Ophthalmol Vis Sci. 2007;48(11):4974-9.

10. Sihota R, Kumar S, Gupta V, Dada T, Kashyap S, Insan R, et al. Early predictors of traumatic glaucoma after closed globe injury: trabecular pigmentation, widened angle recess, and higher baseline intraocular pressure. Arch Ophthalmol. 2008;126(7):921-6.

11. Shen SY, Wong TY, Foster PJ, Loo J-L, Rosman M, Loon S-C, et al. The prevalence and types of glaucoma in Malay people: the Singapore Malay eye study. Invest Ophthalmol Vis Sci. 2008;49(9):3846-51.

12. Khandekar R, Jaffer M, Al Raisi A, Zutshi R, Mahabaleshwar M, Shah R, et al. Oman Eye Study 2005: prevalence and determinants of glaucoma. East Mediterr Health J. 2008;14(6):1349-59.

13. Gadia R, Sihota R, Dada T, Gupta V. Current profile of secondary glaucomas. Indian J Ophthalmol. 2008;56(4):285-9.

14. Bodh SA, Kumar V, Raina UK, Ghosh B, Thakar M. Inflammatory glaucoma. Oman J Ophthalmol. 2011;4(1):3-9.

15. Yaakub A, Abdullah N, Siti Raihan I, Ahmad Tajudin L. Lens-induced glaucoma in a tertiary centre in northeast of Malaysia. Malays Fam Physician. 2014;9(2):48-52.

16. Dada T, Nair S, Dhawan M. Steroid-induced glaucoma. Journal of Current Glaucoma Practice. 2009;3(2):33-8.

17. Kanski JJ, Bowling B, Nischal KK, Pearson A. Clinical ophthalmology: a systematic approach. $7^{\text {th }}$ ed. Edinburgh, New York: Elsevier /Saunders; 2011. 